\title{
Особливості змісту методичної роботи в системі дошкільного виховання України (20-ті - 30-ті роки XX століття)
}

\section{Т. Ю. Шинкар}

\author{
Київський університет імені Бориса Грінченка \\ Corresponding author. E-mail: t.shynkar@kubg.edu.ua
}

Paper received 03.09.19; Accepted for publication 21.09.19.

\section{ttps://doi.org/10.31174/SEND-PP2019-207VII84-09}

\begin{abstract}
Анотація. На основі архівних джерел, аналізу наукової літератури, педагогічного досвіду у статті розкрито особливості змісту методичної роботи в системі дошкільного виховання України (20-ті - 30-ті роки ХХ століття). Розглянуто діяльність керуючих органів державної влади, щодо розвитку методичної роботи в радянській системі дошкільного виховання.

Ключові слова: методична робота, система дошкільного виховання, зміст, форми, методи, розвиток, досвід, історикопедагогічне дослідження, інспектор, заклад дошкільного виховання.
\end{abstract}

Вступ. Розвиток сучасних інформаційнокомунікативних технологій, запити батьків та потреби дітей призводять до змін у змісті та технологіях навчання і виховання дітей дошкільного віку, підвищення рівня організації методичної роботи в закладах дошкільної освіти. Стрімкий розвиток суспільного дошкільного виховання в Україні зумовлює необхідність дослідження історії дошкільної педагогіки та педагогічного досвіду для виокремлення й трансформації продуктивних ідей організації методичної роботи в сучасні умови діяльності закладів дошкільної освіти.

Короткий огляд публікацій з теми. Генеза організації методичної роботи в радянській та вітчизняній освіті розглянуто в працях А. Срмоли, Л. Калініної, О. Капченко, Г. Литвиненко, Т. Ткачевої та ін., але ці праці переважно розглядають розвиток методичної роботи в школі. Загальні теоретичні аспекти методичної роботи в закладах освіти висвітлено у працях I. Жерносек, С. Майданенко, В. Павленко, та ін.; розкрито зміст, форми, особливості організації методичної роботи в сучасних закладах дошкільної освіти в працях Я. Бенцион, Г. Бєлєнької, К. Білої, А. Богуш, О. Долинної, І. Жерносек, О. Кононко, В. Крижко, К. Крутій, А. Морозової, Н. Савінової, Л. Швайки, та ін. Ю. Сирова вивчала організаційно-педагогічні засади методичної роботи в дошкільних навчальних закладах України (друга половина XX століття). Історико-педагогічні аспекти розвитку суспільного дошкільного виховання в Україні, зміст, форми, методи, планування навчально-виховного процесу вивчали: Л. Артемова, О. Бондар, 3. Борисова, О. Венгловська, О. Проскура, Т. Степанова, І. Улюкаєва, та ін. Проте, різноманітність та багатоаспектність наукових досліджень не розкриває повною мірою проблему розвитку змісту методичної роботи в системі дошкільного виховання України (20-ті - 30-ті роки ХХ століття).

Мета. Розкрити особливості змісту методичної роботи в системі дошкільного виховання України (20-ті - 30-ті роки XX століття) в єдності педагогічного досвіду, аналізу наукових досліджень, особливостей розвитку суспільного дошкільного виховання України в зазначений період.

Матеріали і методи. Для досягнення мети дослідження було використано такі методи: хронологічносистемний, конкретно-історичний, історикопедагогічний аналіз, синтез, узагальнення.
Результати та їх обговорення. У 1920 році на першій Всеукраїнській нараді 3 народної освіти було прийнято модель системи освіти України. Відділ народної освіти було поділено на ряд підвідділів, одним 3 яких був дошкільний [2]. У кожному підвідділі передбачалися штатні одиниці завідувачів відділами та інструкторів, що працювали над визначенням організаційних форм та методів керівництва дошкільними навчальними закладами [8]. Цей період представлений працями українських фундаторів дошкільної педагогіки (А. Гендріхівська, О. Дорошенко, С Русова, I. Соколянський, В. Чередніченко, Е. Яновська та ін. На той час українська педагогічна думка розвивалась в загальному контексті побудови й розвитку радянської педагогіки. Праці російських педагогів (Ю. Аркіна, Н. Сакуліної, Є. Тихеєвої, С. Фльоріної та iн.) широко використовувалися в практиці роботи дитячих установ в Україні.

У 20-ті- 30-ті роки ХХ століття суспільне дошкільне виховання лише розпочинало свій розвиток. Базовим питанням було матеріальне та санітарногігієнічне забезпечення дитячих садків. Але не залишалось поза увагою визначення змісту освіти, впровадження нових наукових ідей в практику, підвищення педагогічної майстерності вихователів дитячих установ, що спонукало до розвитку методичної роботи. Методична робота у закладах для дітей дошкільного віку активно розвивалася, хоча це поняття і не використовувалось у широкому педагогічному обігу, а було лише прописане у назвах інструкційних листів, рекомендаціях, положеннях тощо. У 20 - 30-ті pp. XX століття почали активно розвиватися та діяти такі форми організації методичної роботи, як педагогічні виставки, стаціонарні та пересувні бібліотеки, педагогічні музеї, досвідні станції, педагогічні комітети та спеціальні комісії з дошкільного виховання при Народному комісаріаті освіти в Україні. Українські делегації долучилися до участі у Всеросійських з’їздах 3 дошкільного виховання, Всеукраїнських нарадах та конференціях дошкільних працівників. На курсах підготовки дошкільних працівників обговорювалися питання розроблення та впровадження в практику навчальних посібників та методичних рекомендацій 3 фізичного, морального, трудового розвитку дітей дошкільного віку.

На першій Всеукраїнській нараді інструкторів 3 соціального виховання (11-17 жовтня 1921 року) були 
розглянуті питання про роль, форми та методи інструкторської роботи, про інструкторські об'єднання, про плани роботи інструкторів, про схему дослідження дитячих закладів, а також розглянуто Положення про роботу інструкторів на місцях. У нараді взяли участь Харківська, Полтавська, Волинська, Донецька, Кременчуцька та Екатеринославська області. Всі представники виступили 3 доповідями про стан педагогічної роботи, підготовці персоналу, матеріальне забезпечення установ, роботу з дефективними дітьми [19].

В 20-х роках підвідділом дошкільного виховання було розроблено та розіслано до районних відділів ряд інструкцій загально-педагогічного та організаційно-методичного характеру. Також було організовано колектив 3 кращих працівників дошкільного виховання для проведення щонедільних конференцій на яких заслуховувались доповіді та реферати 3 дошкільного виховання. До таких конференцій залучали також батьків вихованців. Недостатня кількість дошкільних працівників змусила відкрити короткострокові курси в 8 містах України, на яких мали підготувати близько 300 дошкільниць [18].

У березні 1923 року у складі губернських відділів освіти були створені інспектури соціального виховання. В коло їхніх обов'язків входило організовувати та забезпечувати діяльності закладів дошкільного виховання у губерніях і повітах, розробляти нові регламентуючі документи 3 питань організації дошкільного виховання, а також контролювати виконання закладами політичних рішень партійних органів та директивних документів державних структур усіх рівнів. Інспектори соціального виховання проводили перевірки усіх підпорядкованих закладів. Але впродовж 20х - початку 30-х років тільки три міста в Україні Київ, Харків і Проскурів (нині м. Хмельницький) мали окремого інспектора 3 дошкільного виховання [1].

Інструкторами підвідділу соціального виховання періодично проводились анкетування 3 визначення змісту діяльності дітей та методів педагогічної роботи в дитячих установах. Анкета містила такі положення: які прийоми застосовуються у роботі вихователя, яка підготовка роботи керівника перед початком кожного робочого дня, чи проводяться заняття за програмою, що покладено в снову програми якою користувався заклад [15].

За наказом організаційно-інструкторського відділу було створено Волостні відділи Народної Просвіти 3 метою розширення просвітницької роботи на селі. У складі відділу, окрім керівника мало бути 2 інструктори: один 3 позашкільного просвітництва, інший 3 дошкільного та шкільного. Для постійного живого зв'язку між периферією та центром раз на місяць планувались збори всіх завідуючих Волостними відділами для виробничих нарад.

У інструкції Волостних відділів освіти зазначалось, що інструктор з соціального виховання стежить за тим, як проводиться навчання у школах, дитячих садках, захистках, дає вказівки щодо організації виховної та навчальної роботи в установах для дітей. Не менше трьох разів на рік інструктор мав відвідати кожну установу та прозвітувати керівнику відділу. Структура доповідей Волостних інструкторів дошкільних ус- танов містила такі положення: як організована робота в дошкільній установі; який режим дня; який характер мають забави дітей, виховуючий, чи лише розважальний; які методи навчання використовуються; взаємостосунки між дітьми та працівниками установ; придатність працівників до роботи з дітьми [17].

У 20-х роках в Україні починають відкриватися методичні кабінети для працівників дошкільної справи, розпочалася активна робота щодо методичного забезпечення дитячих садків. Виходить друком збірник статей «На допомогу дошкільному працівнику» (Н. Альмедінген, Г. Туміма 1925 рік). У збірнику розглянуто деякі аспекти дошкільного виховання. Дошкільна справа визначалася першою сходинкою в системі пролетарської педагогіки. Основний акцент у вихованні дітей спрямрваний на організацію дитячого життя в праці та злиття 3 тогочасною політичною ситуацією [9].

У звітах про роботу окружних і районних відділів освіти до 1925 року містилася інформація, переважно, про організаційні, господарські та матеріальнотехнічні питання забезпечення діяльності в дошкільних установах. 3 методичної роботи дошкільні підвідділи вимагали від вихователів чіткого дотримання режиму, а також рекомендували списки дитячої літератури [1].

У 1926 році було організовано Український науково-дослідний інститут педагогіки (Харків), він став координаційним центром для всієї науковопедагогічної діяльності. Науковці вивчали процес розвитку дитини від одного до семи років, передовий досвід організації роботи дошкільних закладів, брали участь у Всеукраїнських та Всесоюзних з'їздах, створювали опорні садки. В інституті діяла дошкільна секція під керівництвом професора А. Гендрихівської i секція переддошкільництва під керівництвом С. Лівшиної. Секція дошкільного виховання Українського науково-дослідного інституту педагогіки та Науково-методичний сектор Наркомпросу УРСР розробили й видали великим тиражем низку методичних посібників для вихователів щодо організації роботи в дитячих закладах $[1,8]$.

Існували опорні дитячі садки («детский сад-очаг»), в яких принципи дошкільного виховання були дотримані повною мірою. Ці садки ставали центром пропаганди і взірцевої організації дошкільної справи, в них працювали кращі «керівниці». При таких садках організовувалися бібліотеки, музеї життя та творчості дітей, вони були базами для навчальних закладів з підготовки спеціалістів. Показовий садок безпосередньо був підпорядкований місцевим органам Народного комісаріату освіти, матеріальна база, а також заробітна плата працівників була вищою ніж у масовому садку. У штатному розписі передбачено посади методистів. В цих садках вивчався досвід організації дошкільної справи і широко популяризувався на різноманітних педагогічних конференціях, нарадах, з’їздах, у пресі. Вони існували в обласних та районних центрах УСРР (Київ, Харків, Полтава, Донецьк, Маріуполь, Ворошиловськ, Артемівськ та ін.). Загалом, на початку 30-х років кількість зразкових садків була досить обмеженою - не більше 8-10 на всю Україну і розміщувались вони в Одесі, Харкові і Києві $[1,20]$. 
Архівні документи свідчать, що з 1926 року аналіз масового досвіду роботи установ для дітей дошкільного віку та критичного перегляду буржуазної педології сприяв поступовому переходу до планової програмно-методичної роботи в системі дошкільного виховання під керівництвом науково-методичного сектору Управління Соціального Виховання.

Поглиблювалась виховна і методична робота в дитячих садках. Дошкільні працівники вимагали кращих матеріалів для роботи з дітьми, більш різноманітних іграшок, розроблених методичних матеріалів з різних питань виховної роботи. 31931 року в Україні починає видаватися щомісячний журнал «За комуністичне виховання дошкільника» для обміну кращим досвідом i популяризації ідей дошкільного виховання серед населення [10]. В ньому друкувалося багато матеріалів методичного характеру, зокрема з організації різних типів закладів суспільного дошкільного виховання. Журнал значною мірою сприяв підвищенню методичного рівня організації роботи дитячих установ, а матеріали розміщені в ньому дозволяли вихователям знайомитися зі здобутками теорії та практики дошкільного виховання [8].

Формування радянської системи народної освіти тривало до середини 30-х років. У закладах для дітей дошкільного віку вперше було введено обов'язкові державні програми. На III з'їзді Російської Соціалістичної Федеративної Радянської Республіки з дошкільного виховання були підняті питання про створення радянської системи комуністичного виховання, зміст роботи дитячих садків, створення програм для дошкільних закладів.

Наприкінці 1936 року відбулася Республіканська нарада дошкільних працівників, де обговорювались питання про конкретні завдання методичного керівництва, планування та організації роботи дитячих садків. Розгорнулася широка робота над критичним переглядом програм виданих у 1935 році [11].

3 метою поліпшення і поглиблення виховної роботи 3 дітьми в усіх обласних центрах Української РСР і великих містах (Київ, Харків, Дніпропетровськ, Одеса та ін.) було створено сітку обласних та міських кабінетів дошкільного виховання, які глибоко вивчали кращий досвід дитячих садків і широко популяризували його на методичних об'єднаннях і конференціх дошкільних працівників, на сторінках журналу «За комуністичне виховання дошкільника» [12].

Для кращого методичного керівництва зусиллями обласних кабінетів дошкільного виховання і обміну досвідом роботи у 1939 році при Народному Комісаріаті освіти відкрився Центральний науковометодичний кабінет дошкільного виховання [13].

Після Великої Вітчизняної війни центром організації методичної роботи, а також узагальнення і поширення кращого передового досвіду стали кабінети дошкільного виховання інститутів удосконалення вчителів [14].

Кінець 30-х років XX століття - період, коли в результаті напрацювань науковців та практиків були закладені організаційно-змістові засади методичної роботи, затверджено «Керівництво для вихователів дитячого садка» (1938) в якому було сформовано теоретичні, організаційні та методичні основи діяльності дошкільних навчальних закладів в Україні. У 1939 р. відбулося возз'єднання українських земель. Це позначилося і на системі освіти, зокрема були визначені спільні теоретичні, організаційні і методичні основи діяльності закладів дошкільного виховання.

Висновки. Аналіз джерел свідчить, що період 20-х - 30-х років XX століття характеризується становленням радянської системи дошкільної освіти, науковим обгрунтуванням теоретичних, організаційних та методичних основ діяльності дошкільних навчальних закладів. У складний період становлення, зважаючи на існуюче матеріальне та санітарно-гігієнічне забезпечення закладів дошкільної освіти, науковці та практики намагалися визначити зміст освіти, впроваджували нові наукові ідеї в практику, підвищували педагогічну майстерність вихователів дитячих установ. 3'ясовано, що це період активного розвитку форм організації методичної роботи в системі дошкільного виховання, серед яких педагогічні виставки, стаціонарні та пересувні бібліотеки, педагогічні музеї, досвідні станції, педагогічні комітети та спеціальні комісії з дошкільного виховання, підготовчі курси, участь у Всеросійських з'їздах, нарадах та конференціях з дошкільного виховання, розроблення та впровадження в практику навчальних посібників та методичних рекомендацій. Для організації та забезпечення діяльності закладів дошкільної освіти у великих містах, губерніях та повітах створювались інспектури соціального виховання, що дало поштовх для активного розвитку методичної роботи на місцях.

Узагальнюючи дані теоретичного дослідження, можемо констатувати, що особливості змісту методичної роботи в системі дошкільного виховання полягали у тому, що: концептуальні засади розроблялися на загальнодержавному рівні; найбільш успішно методична робота здійснювалась у великих містах України, що було пов'язано з кадровим забезпеченням та матеріальною базою дошкільних закладів; напрацьований досвід методичної роботи обговорювався на з'їдах, конференціях, виробничих нарадах 3 дошкільного виховання і поступово впроваджувався в роботу дошкільних закладів України.

Не всі прогресивні ідеї того часу, що стосувалися методичної роботи в системі дошкільного виховання були втілені у життя. Це обумовлено специфікою соціально-політичної ситуації в державі. Тому вивчення історико-педагогічного досвіду в окреслених рамках дослідження розглядаємо як перспективне.

\section{ЛІТЕРАТУРА}

1. Бондар А.Д. Розвиток суспільного дошкільного виховання в Українській РСР (1917 - 1967) / А.Д. Бондар. - К.: Видво Київ. ун-ту. 1968. - 226с.

2. Дітковська С.О. Становлення системи дошкільного виховання в УРСР (1917-1929 рр.) / Дітковська С.О. // Наук. вісн. Південноукр. держ. пед. ун-ту ім. К. Д. Ушинського:

(зб. наук. пр.). - Одеса, 2003. - № 9/10. - С. 99-107.

3. Дорошенко О. Дитячий садок. - Київ, 1922. - 217 с.

4. Єрмола А.М. Система науково-методичної роботи інформаційно-методичних центрів 3 учителями загальноосвітніх навчально-виховних закладів: дис. ... канд.пед.наук: 13.00.01 / Срмола Анатолій Михайлович. - Х., 1998. - 
$255 \mathrm{c}$.

5. Литвиненко Г.М. Інноваційний розвиток районних (міських) методичних кабінетів $\mathrm{i}$ центрів як науковометодичних установ [Е. ресурс] / Г.М. Литвиненко // Освіта України. - 2012. - №26. - Режим доступу: oipopp.ed-sp.net>metod/1483/1483_1.doc.

6. Про реорганізацію мережі і системи педагогічної освіти. Постанова РНК УРСР від 11.08.1930 р. // Бюлетень Наркомосу УРСР. - 1930. - № 40. - С. 633

7. Ситник А.П. Должность - методист / А.П. Ситник // Методист. - 2001. - № 1. - С. 11-13.

8. Улюкаєва І.Г. Історія суспільного дошкільного виховання в Україні: навч. посіб. / І. Г. Улюкаєва; Бердян. держ. пед. ун-т [та ін.]. - Бердянськ: Колор-Прінт, 2007. - 169 с.

9. В помощь дошкольному работнику / Под ред. Н. Альмединген, Г. Тумима: сб.статей. - Л.: Брокгауз-Еффон,
1925. $-198 \mathrm{c}$.

10. Центральний державний архів вищих органів влади та управління України (ЦДАВОВ України), Фонд 166, оп. 15, спр.2188, арк. 14.

11. ЦДАВОВ України, Фонд 166, оп. 15, спр.2188, арк. 16.

12. ЦДАВОВ України, Фонд 166, оп. 15, спр.2188, арк. 17.

13. ЦДАВОВ України, Фонд 166, оп. 15, спр.2188, арк. 20.

14. ЦДАВОВ України, Фонд 166, оп. 15, спр.2188, арк. 23,24 .

15. ЦДАВОВ України, Фонд 166, оп. 1, спр.921, арк. 118.

16. ЦДАВОВ України, Фонд 166, оп. 1, спр.933, арк. 1.

17. ЦДАВОВ України, Фонд 166, оп. 1, спр.938, арк. 36,38.

18. ЦДАВОВ України, Фонд 166, оп. 1, спр.939, арк. 17.

19. ЦДАВОВ України, Фонд 166, оп. 1, спр.539, арк. 99.

20. ЦДАВОВ України, Фонд 166, оп. 1, спр.199, арк. $30,31,32,57$.

\section{REFERENCES}

1. Bondar A.D. Development of Social Preschool Education in Ukrainian SSR (1917-1967)/ A.D. Bondar. - K.: Publishing House of Kyiv University, 1968. - 226 p.

2. Ditkovska S.O. The Formation of System of Preschool Education in USSR (1917-1929)/ Ditkovska S.O.//Scientific Bulletin of Pivdennoukrainskyi State Pedagogical University Named after K.D. Ushynskyi: (collection of scientific works). - Odesa, 2003. - № 9/10. - pp. 99-107.

3. Doroshenko O. The Kindergarten. - Kyiv, 1922. - 217 p.

4. Yermola A.M. System of Scientific and Methodological Work of Information and Methodical Centers with Teachers of General Educational Institutions: diss. $\mathrm{PhD}$ in Science: 13.00.01 / Yermola Anatolii Mykhailovych. - Kh., 1998. $255 \mathrm{p}$.

5. Lytvynenko H.M. Innovative Development of District (city) Methodological Offices and Centers as Scientific and Methodological Institutions [Electronic resource] /H.M. Lytvynenko //Education of Ukraine. - 2012. - № 26. - Access mode: oipopp.ed-sp.net $>$ metod/1483/1483 1.doc.

6. On the reorganization of the network and system of pedagogical education. Resolution of the RNA of the USSR of 11.08.1930, // Bulletin of the People's Commissar of the USSR. - 1930. - № 40. - P. 633

7. Sytnyk A.P. Position - Methodologist / A.P. Sytnyk // Methodologist. - 2001. - №. 1. - pp. 11-13.

8. Uliukaieva I.H. The History of Social Preschool Education in Ukraine: tutorial / I.H. Uliukaieva; Berdiansk State Pedagogical University. - Berdiansk: Color-Print,

2007. $-169 \mathrm{p}$.

9. To help a preschool worker / Ed. N. Almedingen, H. Tumima: collection of articles. - L.: Brockhaus-Effon, 1925. - 198 p.

10. Central State Archives of Higher Authorities and Governance of Ukraine (CSAHAG of Ukraine), Fund 166, op. 15 , file 2188 , fol. 14 .

11. CSAHAG of Ukraine, Fund 166, op. 15, file 2188, fol. 16 .

12. CSAHAG of Ukraine, Fund 166, op. 15, file 2188, fol. 17.

13. CSAHAG of Ukraine, Fund 166, op. 15, file 2188, fol. 20.

14. CSAHAG of Ukraine, Fund 166, op. 15, file 2188, fol. 23, 24.

15. CSAHAG of Ukraine, Fund 166, op. 1, file 921, fol. 118.

16. CSAHAG of Ukraine, Fund 166, op. 1, file 933, fol. 1.

17. CSAHAG of Ukraine, Fund 166, op. 1, file 938, fol. 36, 38.

18. CSAHAG of Ukraine, Fund 166, op. 1, file 939, fol. 17.

19. CSAHAG of Ukraine, Fund 166, op. 1, file 539, fol. 99.

20. CSAHAG of Ukraine, Fund 166, op. 1, file 199, fol. 30, $31,32,57$.

\section{Peculiarities of the Content of Methodical Work in the System of Preschool Education of Ukraine (20s - 30s of the 20 ${ }^{\text {th }}$} century)

\section{T. Yu. Shynkar}

Annotation. In this article peculiarities of the content of methodical work in the system of preschool education of Ukraine (20s - 30s of the $20^{\text {th }}$ century) are discovered on the basis of archival sources, analysis of scientific literature and pedagogical experience. The activity of the governing bodies of the state power in the development of methodical work in the Soviet system of preschool education is considered.

Keywords: methodical work, system of preschool education, content, forms, methods, development, experience, historical and pedagogical research, inspector, preschool educational establishment. 